\title{
Sainsmatika-based story tale book to improve environmental awareness of 4th grades students
}

\author{
Muhammad Nur Wangid \\ Department of Primary Education, Program Pascasarjana, Universitas Negeri Yogyakarta. \\ Jalan Colombo No. 1, Karangmalang, Yogyakarta 55281, Indonesia. \\ * Coressponding Author. E-mail: m_nurwangid@uny.ac.id \\ Received: 24 October 2018; Revised: 4 November 2018; Accepted: 19 November 2018
}

\begin{abstract}
This study aimed to determine the effectiveness of sainsmatika-based storybooks to improve environmental awareness for students. The experimental research design was used in this study, which involved two classes, namely the control class and the experimental class. Each class consisted of 30 students. The research subjects were 60 students of grade 4 students consisting of 36 female students and 24 male students. The analysis process used an independent $t$-sample test to find out the differences in each outcome. The results showed that based on the gain value obtained, it found out that the average value of the pre-test results in the control class was 49.47 and the posttest result was 67.41. This showed that the increasing score in the pre-test and post-test control classes only reached 2.34 which can be classified as low. Whereas in the experimental class, the results showed that the average pre-test results in the experimental class was 52.63, and the post-test results were 78.90. It means that the students' environmental awareness on pre-test and post-test results were 3.48 , which was in the medium category. The results of the experimental research showed that the use of sainsmatika-based storybooks has a significant impact on students' environmental awareness. The results of hypothesis testing on environmental awareness variables showed that there were significant differences between the control group and the experimental group. The experimental group was better than the control group ( $\mathrm{t}$ count 3.124 at level $\mathrm{p} 0.01)$.
\end{abstract}

Keywords: sainsmatika-based story book, environmental awareness.

How to Cite: Wangid, M. (2018). Sainsmatika-based story tale book to improve environmental awareness of 4th grades students. Jurnal Inovasi Pendidikan IPA, 4(1), 128-135. doi:https://doi.org/10.21831/jipi.v4i1.21706

https://doi.org/10.21831/jipi.v4i1.21706

\section{INTRODUCTION}

The character of a nation is an important aspect in shaping the quality of the nation. Therefore, it is necessary to initiate an idea in regards to improving the quality of a nation; an effort that can be performed is to improve the character of education. Character building must emphasize the development of good characters towards the young generation of Indonesia in order to become a good person all the times. Some scholars believe that the early age of people is the best time to develop a good character. According to Kartadinata (2009), the character of the nation is not only an individual character, but also, since the character of the nation must be manifested in a strong sense of nationhood in the context of diverse cultures. The character of a nation contains cultural values that must implement in cultural awareness and cultural intelligence of every citizen.

Furthermore, aiming to achieve good progress for the Republic of Indonesia, we need a culture with character of strong, competitive, tolerant, cooperative, dynamic characteristics and technically oriented in accordance with Pancasila (Five Pillars of Indonesia) and inspired by faith to God Almighty. Character comes from the person themselves. The character is "an individual's set of psychological characteristics that affect a person's ability and inclination to function morally." A character is a group of psychological characters that affect the ability and tendency of someone's moral function (Damon, 2002, p.48). Therefore, by having this particular character, someone will be guided in thinking as well as in acting. 
Another view, the character interprets as a capability. As a capability, the character is based on the mastery of certain skills. This statement based on Aristotle's thinking. He reviewed the concept of 'ethikearete' or' arete' which is defined as 'excellence of a character' (Lexmond \& Reeves, 2009, p.11). For Aristotle, being good is a set of skills aimed at achieving certain goals in terms of both morals and technical matters. A good character deals with the superiority in pursuing a good life goal of happiness. Happiness as an ultimate goal of life is achieved through life with righteous behaviour both in terms of social relations and self-relations.

The character also affects the personality aspect of a person. Lickona sees the character as an entity supported by three aspects of personality: moral knowledge, feelings, behaviour. Lickona (1992, p. 51) stated that "Good character consist of knowing the good, desiring the good, and doing the good." These three aspects are important factors in building maturity. The concept of character building by Lickona is similar with Ki Hajar Dewantara's: "ngerti, ngroso lan nglakoni" which means that our character can grow through an understanding, feeling, and doing something in daily life. Thus, the character is a basis of attitude and capability which is supported by three aspects of personality: moral knowledge, moral feelings, and moral behaviour. Based on these three domains, a good character is knowing good, wanting good, and doing good.

There are lots of things that can be internalized through character building in elementary school. One of the characters that need more attention is awareness toward their environment. Environmental awareness is a very useful character to enhance students participation for preserve their environment, as well as prevent environmental degradation. Generally, caring defines as giving care to others. This care gives to others. The others might be a person, something, or other reality including the environment (Martin, 2007, p. 58). Caring is a form of character. Caring is a basic attitude that manifests in actions based on affective caring, responsibility, and involvement with others. It is said, "To care is more than a mere act; it is rather an attitude. Therefore, it encompasses more than a moment of awareness, of zeal and of devotion. It represents an attitude of activity, of concern, of responsibility and of an affective involvement with other" (Boff, 2008, p. 14).

Caring means a value to something. Held (2006, p.42) sees caring as a practice and value.
As an act, caring appears in how to respond to the situation or needs and the motives of the behaviour. As a value, caring has standards to use to evaluate the practice or caring actions and may recommend better awareness actions.

Environmental awareness is an attitude and actions which concern in the preservation of the environment and prevent any damage to the surrounding natural environment. A person who has environmental awareness attitude always strives to realize harmony and balance between self and the environment, preserve the environment, and utilize natural resources wisely (Yaumi, 2014, p. 111).

Implementation of character building in schools still faces some similar problems every year. Implementation of new character building is a process of recognition of norms or values students or moral knowledge, instead of moral feeling and moral action. This can lead to the application of character values in a student's life and the building the student's social self-concept cannot be optimally realized. Application of character values in student's life cannot be realized optimally. The reality in the field indicates there are students who do littering, drawing on the desk and lack of exceptions that should train in elementary school age. The action indicates moral degradation among students. It also shows that they have not been able to interact and maintain good social relationships with people in their neighborhood.

Although the environmental awareness character has an important role in the development of someone's personality, the character still become one of the weaknesses of Indonesians. Lack of awareness within students caused the lack of awareness toward their environment. Based on descriptions, environmental awareness still becomes one of the weaknesses of Indonesian, either children or adults. Meanwhile, environmental awareness becomes one of the characters that must behave by Indonesian aiming to be a superior person. Therefore, the character needs to be taught as early towards the children, aiming to prepare them into a superior Indonesian personality.

The environmental awareness character supports positive character building for students. Daryanto \& Darmiatun (2013, p.49) suggested that discipline serves to balance between independence, confidence, and positive relationships with others so that the person can adapt to their surroundings optimally. In the implementation of Curriculum 2013 for elementary school, environ- 
mental awareness character is a social attitude competence that must be mastered by fourth grade students. In Core Competence 2, on social attitudes, the behaviors that must be positively showed by students are honest, discipline, polite, confident, caring, and responsible in interacting with family, friends, teachers, neighbors, and state (Kementerian Pendidikan dan Kebudayaan Republik Indonesia, 2016, p.6). Therefore, environmental awareness is one of the characters that must be had by students. The positive character also plays an important role in the social interaction between students and their environment. By having a positive perception of its ability in maintaining health and environmental hygiene, it will strengthen the character of the Indonesian. One of the most important roles in facilitating in embedding the environmental awareness is the school.

School is one of the fundamental to achieve the function in building human beings who have environmental awareness character. Aiming to build an environmental awareness character within students, school must provide learning experiences and positive motivation to students. And, we can preserve the sustainability of our environment. Erhabor \& Don (2016, p. 5369) mentioned that characters can be formed through, “... increasingly challenging to get students interested in classroom lessons, environmental education offers an enriching way for both students and teachers to connect their appreciation of natural to academic. .....". Indirectly, it might interpret, if learning in the class makes students are interested, and then it will impact to the cognitive and affective of students.

One of the efforts to assist students in improving environmental awareness in character education is by applying instructional materials to support integrated learning character education based on student's character. Learning instructional materials can facilitate students to develop critical understanding, stimulate students to actively participate, and make the learning curriculum relevant to student life (Buckingham, 2012, pp. 4-5). Integrated learning media and character education can facilitate students in mastery the concepts and character values in the learning materials. Building an environmental awareness character might also be conducted through a habituation. Various programs in the school can use to build character. According to Yaumi (2014, pp. 142-143) habituation might conduct by integrating the concept of environmental awareness character in content and learning activities using a book which the book have an interesting and easily understood by students. The form of supporting book is a science-based story book which is very effective to improve environmental awareness. Students are taught by listening and reading their own science-based story book that contains the value of environmental awareness characters and presented a series of stories related to problemsolving. As the effect, the students are able to solve problems of their environment.

Habituation activities can also be done through slogans that can foster the growing good habits in managing and caring the environment in the school. For example: "Come on, Love Our Environment!", "Great Boys throw garbage in its place", "Time to be an Environmental Care Agent!" and many more.

Science-math is the continuity of the concept of integration applied in Curriculum 2013. Based on the scope between science and mathematics, the content of this lesson is very influential in learning activities, especially in primary schools. Kready's statement (2004, p. 9) referred to a synthesis that story tales provide an opportunity for the child's readers to build personality from their experiences through reading. In line with that the statement, story tales must provide advices for students.

The content of Science and mathematics has similar characteristics. Mathematics and science are lessons containing facts, concepts, principles and scientific laws that teach through certain steps or methods aiming they can be delivered properly. If the teaching method is not appropriate, the objectives of science and math learning will not be achieved. Today, science and mathematics tend to be difficult to be understood by students. Therefore, according to some previous expert opinions, it needs a fun way of learning science and mathematics. The problem of science and mathematics, in this case, refer to the Core Competence and Basic Competence in the fifth grade book of Curriculum 2013. One of them is through literature culture such as story tale. Students are able to develop their character values when they feel comfortable and fun with the lesson. Marpaung (2012, p.191) explained that learning science is a fun things, such reading a book. However, a fun learning is not only using ordinary learning books but can also use story books. Thus, story book become a means to convey knowledge such as the material of science and convey the values of character. 


\section{Jurnal Inovasi Pendidikan IPA, 4 (1), 2018 - 131}

Muhammad Nur Wangid

The science-based story book is a story tale that is able to provide a positive contribution in the education process to bring science and mathematics material into a story tale and supported by a variety of interesting activities in line with the achievement of learning competence aiming facilitate the increase of environmental awareness. According to the previously mentioned materials, the authors assumed that there is a link between the uses of teaching materials in the form of a science-based story book in improving the student's caring character. However, there have no conducted research related to the problem. Therefore, it is necessary to examine on the how effectiveness the influence of the science-math based story book in improving the student's caring character.

The problem in the particular research was; how effective the science-math based story book in improving the character of environmental awareness in the fourth grade students of State Elementary School (SD Negeri) 1 Bantul. The purpose of this study was to find out the effectiveness science-math based story book in improving the character of environmental care in the fourth grade students of SD Negeri 1 Bantul. The findings of this study are expected to provide benefits in terms of theoretical information and increase understanding to scientific theories in the field. The practical benefit for readers is to provide additional insight on the innovative reading book and able to facilitate environmental awareness character, as well as for teacher to consider the book as reference of teaching materials in carrying out learning process to improve the caring character of elementary school students.

\section{METHODS}

This research was an experimental research, consisting of an experimental class and a control class. The purpose of this design was to identify whether there is a difference between the control group and the experimental group using the story book and to analyze the influence of using story book in experimental group towards the environmental awareness. Research samples. The population in this study consisted of 60 students: 36 female students and 24 male students. Each class consisted of 30 students. The respondents were selected by purposive sampling technique where the subjects were only students who attended in primary school and appointed as national curriculum pilot project in Indonesia.

\section{Instruments}

This main instruments of this study were (1) observation guide and (2) questionnaire. The observation guide used to observing student environmental care character, and the questionnaire used to inquire about student perspective and activity about environmental care.

\section{Data Analysis}

The data collection was collected through questionnaire of the environment. Data analysis. The collected data of quantitative data is then descriptively analyzed using independent t-test. The analysis conducted to determine the significances of the use of science fiction story the character of environmental awareness.

\section{FINDINGS AND DISCUSSION}

Based on the collected data through the questionnaire, the environmental awareness character of the students treated with book of science story showed a significant improvement compared with the control group that did not treat using science fiction story book. The measurement of the students' caring character conducted through the questionnaire instrument. Questionnaires were given before and after the lesson using a science fiction book. The questionnaires provided in the meeting of learning before treated using science-based story and used as pre-test data. Meanwhile, in the meeting, treated using science-based story book were used as post-test data. The summary of pre-test and post-test score of environmental care questionnaire in control and experiment class is presented in Table 1.

Table 1. The Summary of Pre-test and Post-test Score of Environmental Care Questionnaire

\begin{tabular}{lcccc}
\hline \multirow{2}{*}{ Class } & \multicolumn{2}{c}{ Average } & \multirow{2}{*}{ Gain } & \multirow{2}{*}{ Criteria } \\
\cline { 2 - 3 } & Pre-test & Post-Test & & \\
\hline Control & 49.47 & 67.41 & 2.34 & Low \\
Experiment & 52.63 & 78.90 & 3.48 & Medium \\
\hline
\end{tabular}

The result of measurement towards student's caring character through the questionnaire given to the control class as a class that carried out the lesson only by using the theme book and the experimental class as a class that used the theme book and supported by teaching materials in the form of the science-math based story book. Diagram 1 is the result of descriptive analysis of the questionnaire results on the learning. 


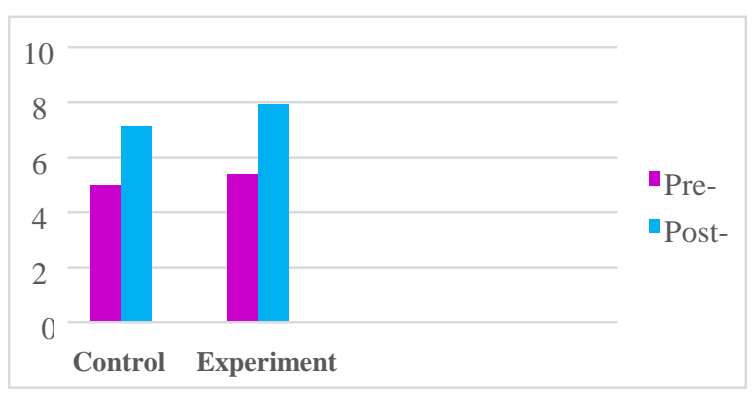

Figure 1. Comparison of Improvement on Environment Awareness Character Building Based on Questionnaire

According to the result of measurement through questionnaire, the average score of pretest is 49.47 and posttest is 67.41 in the control class. So, the gain score of pre-test and post-test of the control class only reaches 2.34 and classified into the low category. Means, the control class does not experience a huge increasing. In the experimental class, the average score of pretest is 52.63. Meanwhile, the score of the posttest is 78.90. Means, the result of pre-test and post-test of the student's caring character in the experimental class is 3.48 , and classified in the medium category. The gain score in the experimental class is higher than in the control class. Therefore, the science-based story book might claim as an effective way to improve the fourth grade student environmental awareness.

Table 2. Significance Test of Character of Environmental Care based on the questionnaire

\begin{tabular}{ccc}
\hline \multirow{2}{*}{ Variable } & \multicolumn{2}{c}{ Comparison } \\
\cline { 2 - 3 } & $\mathrm{t}_{\text {table }}$ & $\mathrm{t}$-test \\
\hline Environmental Care & 1.987 & 3.124 \\
\hline
\end{tabular}

Table 1 showed the differences in the environmental awareness characters between control groups and experimental groups which treated with a science fiction textbook. This is implied on the test results of significance difference using ttest formula (independent samples t-test). Based on the result of t-test, the score of environmental care is 3.124. And, the score of t-table is 1.987. The criteria of decision making are that if t-count is greater than $\mathrm{t}$-table; then $\mathrm{Ho}$ rejected and $\mathrm{Ha}$ accepted. Thus, it has been proved that there are differences in environmental cares between experimental groups using science fiction books and control groups that do not use the sciencemath based story book in learning. The analysis result of the environmental-care questionnaire indicates that the increasing score of environmental cares in the experimental class is higher than the control class. The gain score of the environmental-care character in the experimental class is 3.48 and in the medium level of effectiveness. The gain score of the environmental-care character in the control class is 2.34 and in the low level. Therefore, based on the questionnaire results, the science-based story book might claim as effective in improving the environmental caring character on fourth grade students.

Based on t-test result, t-count environmental care score is 3.124. While table score is 1,987. Criteria of decision making are that if $t-$ count is greater than t-table; then Ho rejected and Ha accepted. Thus, it has been proved that there are differences in environmental cares between experimental groups using science fiction books and control groups that do not use science story book in learning. Books based on science-based story might claim as effective to improve the environmental care character of the fourth grade students in SD Negeri 1 Bantul. This is obtained from the consistent results of questionnaires which conducted repeatedly. Caring is a form of character. It includes an attitude of activity, of concern, of responsibility and of an affective involvement with other (Boff, 2008, p. 14). Caring is a basic attitude that lays on actions according to affective attention, responsibility, and involvement with others. Furthermore, the environment will be healthier if there is a harmonious relationship between human and nature. According to Nazir (2013, p.2), environmental education needs to be im-proved to embed a culture that leads to a healthy human being, as well as a healthy environment. And also, it is to encourage more comfortable interaction between humans and nature. Therefore, pictorial stories in science-based story can be used to change the behavior and attitude of the child into more positive.

The story can facilitate the development of the child's mental process in thinking and making decisions on various issues. Children are trained in making rational, relevant and logical decisions. In line with Kredy (2004, p.9), stated that besides providing a reinforcing experience, story also able to become a means of entertainment in order the children feel happy and gain new experiences. Fairy tales (story) bring joy into child life. The mission of joy has not been fully taught, but in fact, joy works toward physical health, mental, brightness, and virtue morale. Fairy tales can bring pleasure in a children's life. Pleasure is not only to be felt, but also influence on physical health, mental and moral development of 
children. Fairy tales give children opportunity to build their personality from experiences through reading. Fairy tale can increase the joy and positive energy for anyone who enjoys it. Huck, Hepler, \& Hickman (1987, pp. 54-61) stated that the benefits of child's literary have a positive influence in terms of intrinsic and extrinsic elements. Extrinsically, fairy tales have an inner use directly or indirectly for the children. While extrinsic is an outward use. In general, intrinsic benefits of fairy tales are: (1) give pleasure, joy, and enjoyment; (2) develop children's imagination; (3) provide new experiences; (4) develop children's insight, and (5) preserve the cultural heritage from generation to generation.

The use of fairy tales as a means of learning in an effort to improve the development of elementary school children considered as very appropriate. Moreover, Huck, Hepler, \& Hickman (1987, pp. 6-14) suggested that the fairy tale as child literature broadly divided into two groups: personal values and educational values. Personal values, fairy tales might provide beneficial for the development of children, such as improving emotional development, intellectual development, imagination development, the growth of social sense, and the growth of ethical and religious. In fairy tales book, material of theme 6 in fourth grade, positive environmental care characters for 4th grade students is developed, explored and linked to the context of daily life through fairy tales with drawings illustrations telling the plot of stories and activities and facilitate the environmental awareness character. In line with Kurniawan (2013, p.47) stated that through the material of developed, explored and linked to the context of everyday life, character values of learning are not only in cognitive domain, but it might also achieve internalization and actualization values of characters in daily life, among in the environment of family, school, and society.

The process of learning science and math is not only through the textbooks to assist children in the learning process, but also might be through the story book. Through children's story book, it can also make the learning process more interesting and fun. It is not only using books such a textbook, but also through a different media such story book. Other references also found out that the fairy tale as a media can be used in the process of delivering material of mathematics subject. Anderson (2009) stated that "Fairy tales include a number of notions which help children get mathematical notions about the surrounding world, it's variety and glory. Fairy tales not only develop children's imagination but also develop their skills to use mathematical connections and basic notions in a simple understandable language in primary and preschools mathematic education, at the same time putting stress on these connections and so paving the way to further serious acquisition of the systemic course of mathematics".

Fairy tales include a number of notions which help children get mathematical notions about the surrounding world; the fairy tale not only develops children's imagination but also develops their skills to use mathematical connection. This study aims to continue the research of Anderson which states that learning through fairy tales will make it easier to learn mathematics. There is a difference that science fiction tales not only learn on mathematical, but also the connection between science and mathematics. Based on the opinion, it becomes the reason on fairy tale book as one of the teaching materials to support the achievement of learning objectives; especially on the content of science and mathematics material in line with the material. The sciencebased fairy tale book claim effective for improving the environmental awareness character. As seen from the results of questionnaires, the results are fixed, steady, and accurate. Caring is a form of character.

Caring is a basic attitude that manifests in actions based on affective attention, responsibility and involvement with others. Furthermore, the environment will be healthier if there is a harmonious relationship between humans and nature. According to Nazir $(2013$, p. 2) stated that environmental education needs to be improved to foster a culture that leads to healthy human beings, as well as a healthy environment. And also, it is an effort to encourage more comfortable interaction between humans and nature.

In connection with this research, the science-based fairy tale book is effective in improving the students' caring character. The increase the student's caring character due to a series of facilities in the book of fairy tales presented in the form of science and math activities such as activities, "Now I Know", "Let's Think", "I Can Conclude", "Let's Test the Abilities," which is compiled based on the indicators of environmental awareness characters; (1) Caring for environmental sustainability, and (2) Preventing damage to the surrounding natural environment. In addition, the facilitation of environmental awareness character is also shown 
through exemplary characters in fairy tale "Sainsmatika Adventure on the Equator, who have the nature of care and willing to know everything. Thus, the science-based fairy tale book has been declared "effective" in improving problemsolving abilities and students' environmental caring character. As in the study by Kredy (2004, p. 9). In addition, aiming to providing reinforcing experiences, fairy tales can also bring pleasure in the lives of children. The pleasure is not only to be felt, but also have an effect on the physical health, mental and moral development of the child. Fairy tales give children the opportunity to build their personality from experiences through reading.

In addition, Anderson (2009, p. 10) describes the research results that fairy tales include a number of ideas and help children acquire mathematical knowledge of the surrounding world. Which is demonstrated by not only developing children's imagination, but also it develops the skills to use in the mathematical connections. The position of this particular study is to equally improve cognitive and affective skills through the book of fairy tales. But, this research is more specific to improve the character of environmental care. So, not all cognitive and affective aspects are developed. Based on the questionnaire, the improvement of students' environmental care characters in the experimental class is higher than the control class. Thus, it might be concluded that based on the questionnaire, the science-based fairy tale book can claim effective to improve the students' environmental awareness character with the level of effectiveness. Lickona (1992, p. 295) argues that moral reflection plays an important role in building the cognitive aspects of student character and plays an important role in students to make moral judgments about their own behavior and the behavior of others.

The use of theme books that are considered not maximal in facilitating the achievement of learning objectives, provide a new view to researcher to contribute in the world of education. This science-based fairy tale book is packaged creatively and innovatively in providing science and mathematical activities to facilitate the development of environmental caring character in fourth grade elementary school students. The book will be very helpful for teachers and students in strengthening knowledge in line with the respective subjects. In line with opinion (Prastowo, 2015, p. 79) the textbook book is a textbook compiled for the learning process and contains the materials or learning materials that will be taught in the class. Based on the opinion, it also becomes the reason why book of fairy tale as means of teaching materials to support the achievement of learning objectives, especially on the content of science and mathematics lessons in accordance with the content of lessons.

More specifically, the science-math based fairy tale book can help students in developing environmental-awareness characters. The statement is supported by a pilot project conducted by Wangid, Mustadi, Erviana, \& Arifin (2014) in the Province of Yogyakarta. In the pilot project, it developed the thematic-integrative learning tool based on socio-cultural. The results showed that the device effectively improves the students' learning outcomes and character. Based on the research, this study attempted to prove that the science-mathematical based on fairy tale book able to improve the character, specifically, concerned on the environment.

\section{CONCLUSION}

Based on the results and findings, the score of t-count of environmental awareness character is 3.124 with level $\mathrm{p} 0.01$. In other words, there are differences of student's environmental awareness characters between experimenttal group and control group, and the student's awareness (caring) environmental character in the experimental group is better than control group. Thus, concluded that the application of science-mathematical fiction of fairy tales in learning process proved effective positive implications on the student's caring character. This study showed that a fairy tale book has an element of character education and might use in teaching in primary schools.

\section{REFERENCES}

Anderson, R. (2009). Trough fairy-tales to Math in the lesson. Acta Didactica Napocensia, 2 (2), 112-118.

Boff, L. (2008). Essential care an ethics of human nature. Texas: Baylor University Press.

Buckingham, D. (2012). Media education: literacy, learning an contemporary culture. Cambridge: Polity Press.

Damon, W. (2002). Bringing in a new era in character education. California: Hoover Institution Press. 


\section{Jurnal Inovasi Pendidikan IPA, 4 (1), 2018 - 135}

Muhammad Nur Wangid

Daryanto, D., \& Darmiatun, S. (2013). Implementasi pendidikan karakter di sekolah. Yogyakarta: Gava Media.

Erhabor, N. I., \& Don, J. U. (2016). Impact of Environmental Education on the Knowledge and Attitude of Students towards the Environment. International Journal of Environmental and Science Education, 11(12), 5367-5375.

Held, V. (2006). The ethics of care: Personal, political, and global. New York: Oxford University Press, Inc.

Hendarson, K. L \& Malone, S. L. (2014). Ethical fairy tales: using fairy tales as illustrative ethical dilemmas with counseling students. Journal of Creativity in Mental Health. 7 (1), 64-82.

Huck, C. S., Hepler, S., \& Hickman, J. (1987). Chindren's literature in the elementary school. New York: Holt, Rinchart and Wiston.

Kartadinata, S. (2009). Mencari bentuk pendidikan karakter bangsa. Makalah. Fakultas Ilmu Pendidikan. Universitas Pendidikan Indonesia. Bandung. 74121 sunarya_kartadinata/mencari_bentuk_pendi dikan_karakter_bangsa.pdf.

Kementerian Pendidikan dan Kebudayaan Republik Indonesia. (2011). Panduan pelaksanaan pendidikan karakter. Jakarta: Badan Penelitian dan Pengembangan Pusat Kurikulum.

Kready, L.F. (2004). A study of fairy tales. Boston: The Riverside Press.

Kurniawan, S. (2013). Pendidikan karakter: konsepsi dan implementasinya secara terpadu di lingkungan keluarga, sekolah, perguruan tinggi, dan masyarakat. Yogyakarta: Ar Ruzz Media.
Lexmond, J., \& R. Reeves. (2009). Building character. London: Demos.

Lickona, T. (1992). Educating for character how our school can teach respect and Responsibility. New York: Bantam Books.

Marpaung, M. (2012). Sekarang aku tahu: Sains dalam dongeng, fabel, legenda, dan cerita rakyat. Yogyakarta: Galang Press.

Martin, P. (2007). Caring for the environment: challenges from notions of caring. Australian Journal of Environmental Education, 23, 57-64.

Marzuki, M. (2013). Revitalisasi pendidikan agama di sekolah dalam pembangunan karakter bangsa di masa depan. Jurnal Pendidikan Karakter, III(1), 64-76. https://doi.org/10.21831/JPK.V0I1.1288

Nazir, J. (2013). Connecting, care and agency: the nature of environment education at an outdoor education centre. Ontario: Toronto University.

Prastowo, A. (2015). Panduan kreatif membuat bahan ajar inovatif: menciptakan metode pembelajaran yang menarik dan menyenangkan. Yogyakarta: Diva Press

Wangid, M. N., Mustadi, A., Erviana, V. Y., \& Arifin, S. (2014). Kesiapan guru SD dalam pelaksanaan pembelajaran tematik-integratif pada kurikulum 2013 di DIY. Jurnal Prima Edukasia, 2(2), 175-182. https://doi.org/10.21831/jpe.v2i2.2717

Widiyoko, E. P. (2009). Evaluasi program pembelajaran: panduan praktis bagi pendidik dan calon pendidik. Yogyakarta: Pustaka Pelajar.

Yaumi, M. (2014). Pendidikan karakter landasan, pilar \& implementasi. Jakarta: Prenada media Group. 